\title{
A Refugee Camp Conundrum: Geopolitics, Liberal Democracy, and Protracted Refugee Situations
}

\author{
JENNIFER HYNDMAN
}

\begin{abstract}
Liberal democratic norms are embodied in refugee camps and the states that host them in a multitude of ways: through refugee law and the 'good offices' of the United Nations; in relation to international aid and the prerequisites recipient governments must meet to receive it; and in refugee education to name but a few. In the Dadaab camps of Northeast Kenya, democracy and law meet intense geopolitical pressures. The camps are situated in what was once contested territory during the period of colonial rule. In the early 1990s and again in 2011, as Somalia faced armed conflict and related famine, thousands of refugees fled to the Dadaab camps. The presence of Somali refugees in Kenya is not politically neutral or merely humanitarian. The contradictions between liberal democratic norms and the prevailing geopolitical sentiments that favour keeping refugees in camps them are explored in the context of Dadaab.
\end{abstract}

\section{Résumé}

Des normes démocratiques libérales sont appliquées dans les camps de réfugiés et les États qui accueillent ces camps le font de plusieurs façons: par des lois sur les réfugiés et les bons offices des Nations Unies, par l'aide internationale donnée aux États sous certaines conditions, et à travers l'éducation auprès des réfugiés, pour n'en nommer que quelques unes. Dans les camps de Dadaab, dans le nordest du Kenya, la démocratie et la loi subissent des pressions géopolitiques intenses. Ces camps sont situés dans un territoire autrefois contesté pendant la période coloniale. Au début des années 1990 et de nouveau en 2011, des milliers de réfugiés ont fui vers les camps de Dadaab, suite au conflit armé en Somalie et à la famine qui en a découlé. La présence de réfugiés somaliens au Kenya n'est pas une situation politiquement neutre ou simplement humanitaire. Les contradictions apparaissant entre les normes démocratiques libérales et les sentiments géopolitiques prédominants en faveur de garder ces réfugiés dans les camps, font l'objet de cet article, dans le contexte des camps de Dadaab.

\section{Introduction}

As a field of inquiry, 'refugee studies' is remarkably apolitical given the dramatic human displacement across borders that geopolitics generates. Conflict in and displacement from Somalia today, for example, are imbued with legacies of the Cold War, as weapons left behind by allies from the USSR and later from the US can still be found in use. The Dadaab camps of Northeast Kenya are located in what was once contested territory between Somalia and Kenya during the period of colonial rule. The refugees' presence in the region today is not politically neutral or merely humanitarian.

Herein lies the conundrum; others might call it a contradiction, or more simply geopolitics. Most of the world's states have signed the 1951 Convention Relating to the Status of Refugees or the 1967 Protocol that extends its temporal and geographical mandate, yet the wealthiest of these have found ways to duck many of the legal obligations outlined therein. This same Convention also outlines certain rights to education that refugees shall have. In short, liberal democratic norms and human rights might appear to ensure the provision of protection and education to refugees, but the actual aid, policies and strategies of these liberal democratic governments do not always correspond to these legal 
obligations and democratic norms. Instead, refugees are managed in situ, stuck in legal limbo without most of the basic human rights to mobility, work, and residence. While non-refoulement, or protection from forced return to a dangerous country of origin, remains intact, refugees in Kenyan camps live with long term uncertainty, with their mobility, employment prospects, and legal status restricted.

This short paper makes three related points that advance this argument. First, I outline how refugee camps themselves are geopolitical formations and are in no way immune or irrelevant to geopolitics, whether regional or international. Then I draw on research to show how Somali refugees in the Dadaab camps of Kenya are managed in place, with little concern for the ongoing suspension of livelihoods and human development. ${ }^{1}$ Finally, based on the first two points, I elucidate the hypocrisy of the long term camp situation in a context where international aid to refugee-hosting countries is conditional upon democratic reform, 'good governance', and other liberal norms that value civil society that are completely ignored in the context of the camps. One expression of this dark irony is refugee education in the camps. To conclude, then, I offer evidence of refugee education in the Dadaab camps as an expression of liberal democratic norms in a place where such norms are largely being ignored or neglected in relation to the protracted refugee population.

\section{The Geopolitics of Humanitarian Space}

The Horn of Africa, including East Africa, has been a strategic space subject to foreign influence during colonial, Cold War, and postcolonial periods, including the contemporary one. European powers staked their claims in the Horn of Africa beginning in the latter part of the nineteenth century, notoriously drawing international borders through single ethnic and linguistic groups and destabilizing the region in the process. In the contemporary moment, the people at whom humanitarian assistance is targeted are largely found in poorer, formerly colonized countries of the geopolitical 'Third World', those states of the Non-aligned Movement that chose to side neither with the First World capitalists or the Second World communists. More than $80 \%$ of refugees today live in the global South, with a large number of those in Sub-Saharan (and increasingly North) Africa. ${ }^{2}$ The huge flow of humanitarian capital into Africa-in the form of peacekeeping and refugee relief-is far more impressive than the number of refugees and displaced persons who are allowed to leave. ${ }^{3}$

This section of the paper briefly examines relevant colonial, Cold War, and post-Cold War investments in the Horn of Africa. It highlights the relationship of colonizer to colony as this was superimposed upon nationalist claims for an ethnonational state during the period of independence, followed by flows of money and arms from superpowers to countries in the Horn during the Cold War. My analysis aims to highlight how politically charged humanitarian spaces can be, and provides a context for the current round of humanitarian crisis that besets this region today.

The borders that produce refugees and circumscribe their movement in East Africa and the Horn today are predicated on colonial and Cold War political geographies. The establishment of borders during the colonial period was reinscribed by infusions of arms and other investments during the period of superpower rivalry. Today these borders continue to be reinforced by the large, and no less political, flows of humanitarian assistance. ${ }^{4}$ Today, the flow of 'First World' resources into the region continues, albeit to serve ostensibly humanitarian rather than colonial or superpower interests. The relative immobility of refugees to leave the region has been juxtaposed with the hypermobility of donor capital to the region. ${ }^{5}$ More recently, notable funds have been made available by governments in the global North to develop tactics to keep prima facie refugees in 'regions of origin' and prevent asylum seekers from entering their territory.

\section{Drawing the Line, Dividing the Nation: Kenya and Somalia}

Most Somalis in Kenya live in Northeastern Province, along the Kenyan-Somalia border, a region formerly known as the Northern Frontier District (NFD). The territorial difference between the Somali nation, as the variegated ethno-national group of all Somali people in Kenya, Somalia, Ethiopia, and the Somalian nation-state has been a major source of geopolitical conflict in the region throughout colonial, Cold War, and contemporary periods.

The Government of Kenya (GOK) has not hidden its disdain for Somali refugees living in Kenya, or for its own Kenyan nationals of Somali ethnicity. Racism and discrimination against Somalis are practiced today just as they were during the colonial period in which Britain ruled Kenya and Northern Somalia, France controlled Djibouti, and Italy occupied Southern Somalia. While the first colonial powers in the Horn exercised only a maritime presence, the 'scramble for empire' among European nations in the late nineteenth century accelerated the process of colonial partition. Unsurprisingly, many borders in Africa were drawn with European interests rather than indigenous settlement patterns or local politics in mind. Conflict over the Kenya-Somalia border can be traced back to colonial occupation at the turn of the century when Britain extended control over the semi-arid region now known as the Northeast Province of Kenya. ${ }^{6}$ 
The British colonial administration wanted to establish a 'buffer zone' between its borders with Ethiopia and Italian Somaliland (now Somalia) on one side and its railway and white settler population on the other. ${ }^{7}$ Accordingly, administrative boundaries were redrawn within Kenya, creating the Northern Frontier District. The 'frontier' in the district's name was elucidated in 1909 when Somalis living in Kenya were prohibited from crossing the Somali-Galla line that divided the NFD from the rest of Kenya. This early effort to contain Somalis in Northeast Kenya led to strategies by subsequent governments to curtail the mobility of Somali Kenyans in relation to other Kenyan nationals. ${ }^{8}$ Today, while Kenyan Somalis are no longer subject to such discriminatory restrictions, all refugees (most of who are from Somalia) in the Dadaab camps, which are located in this same part of Kenya, are required to stay in the camps.

The 1909 policy generated significant resistance to colonial rule on the part of Somalis. In response, the British administration-by means of legal ordinance-declared the NFD a closed district in 1926, a move which afforded it broad powers to sweep the Somali problem behind the line, as it were, using whatever force was necessary. A subsequent legal ordinance designated the NFD a 'Special District' that required its Somali inhabitants to carry passes or seek approval from authorities to enter other districts. Little attempt was made by the colonial administration neither to promote neither social nor economic activities in the district nor to integrate it politically with the rest of Kenya. This geographical and socio-economic segregation continued even after Kenya achieved independence. Today, this part of the country remains distinctly poorer and less politically powerful compared to the rest of Kenya.

In 1960, British Somaliland, located in the northern part of the emerging country, united with Italian Somaliland in the South to form the independent Somalian Republic. Despite the formation of this new state, many Somalis remained outside its borders in the Ogaden region of Ethiopia and in the Northern Frontier District of Kenya. Ethnic nationalism and the quest for the unification of the pan-Somali nation under the leadership of the new government of the Republic of Somalia intensified the struggle for self-determination among Somalis in Kenya, whose persistent political efforts succeeded in pushing the British Colonial Secretary to call for a commission that would determine the public opinion of the NFD. A United Nations Commission was then appointed to consult residents of the area and to make recommendations accordingly. ${ }^{9}$

The Commission found that ethnic Somalis in Kenya overwhelmingly preferred unification with the Somalia Republic to their political status as part of Kenya. The British colonial administration was, however, also in the process of negotiating Kenyan independence at the time with president-to-be, Jomo Kenyatta. During these talks, Kenyatta made it clear that he refused to cede Kenyan Somaliland to its neighboring republic. The British administration decided to placate Kenyatta by quickly writing its own Report of the Regional Boundaries Commission, a paper that recommended its preferred course of action and reneged on its promise to follow through with the UN Commission's recommendations. ${ }^{10}$

When this decision was announced, the Somalian Republic severed its diplomatic ties with Britain and mounted an insurrection in Northeast Kenya which became known as the 'Shifta War.' Shiftas were, and still are, defined as bandits. Bandit activity is related to the systematic economic marginalization of ethnic Somalis living in this region of Kenya, the Northeast Province of Kenya being one of the poorest regions in the country. By relegating resistance in the area to mere regional 'banditry', the British administration tried to undermine the political legitimacy of Somali actions. In efforts to counter resistance, the colonial administration of the day declared a 'state-ofemergency' in the district in March 1963. Immediately after Kenya's independence in December 1963, the newly independent Kenyan government also declared a stateof-emergency in the Northeastern Province and held the Somalian government responsible for rebel activity in the region. ${ }^{11}$

After Kenyan independence, the political struggle for the unification of a Somali nation continued at regional and continental levels. Somalia looked for support from the Organization of African Unity (OAU), founded in 1963, but found none. While the OAU admitted that the borders of post-independent African states were artificial, it was committed to territorial integrity and the survival of these borders as a practical compromise to achieve peace among African states. Between 1964 and 1967, reports suggest that some 2,000 Somalis were killed by Kenyan security forces. ${ }^{12}$ The position of the Government of Kenya, which vowed not to cede any ground to Somalia, had very material implications for Kenyan Somalis. In the struggle to gain independence from colonialism, the new Kenyan government was complicit and reinscribed the colonization of the Northern Frontier District. Soon after, expelling inhabitants of the area became a means of addressing Somali resistance and rectifying insecurity in the region. Although the Republic of Somalia formally renounced its claim on the Northeast Province in 1967, the state-of-emergency policy remained in effect in the region until 1991. 
The Militarization of the Border Area: Now and Then

The militarization of both countries through this period is worthy of its own study, yet both this story and the history of conflict in Kenya's Northeast Province point to the area as one that is hardly neutral, despite its humanitarian and refugee camp monikers. This point has been highlighted throughout the fall of 2011, as insecurity became a feature of the Dadaab camps themselves. In October, two Spanish doctors working for Medecins Sans Frontieres (MSF) were abducted in the camps. ${ }^{13}$ Their kidnapping remains a mystery at the time of writing, and many more security incidents targeted at Kenyan police in and around the camps have undermined security, inculcating 'banditry' of a new order.

Returning to the summer of 1992, the confluence of drought and conflict in Somalia led to acute famine and displacement both within the country and beyond its borders. Widespread famine and the collapse of the Somalian state exacerbated this situation in which an estimated 500,000 Somali citizens died. Well over a million Somalians were internally displaced and some 600,000 fled the country, many of them seeking asylum in nearby Kenya. While they were not warmly welcomed, the Kenyan government was obliged to tolerate them, partly because of its commitment in international law to the 1951 Convention and 1967 Protocol relating to the Status of Refugees as well as the 1969 OAU Convention, and partly because it needed the continued support through foreign aid of donor countriesmany of which had suspended funds to Kenya at that time.

While donor countries awaited a satisfactory outcome of the country's first multi-party elections before reconsidering their aid commitment to Kenya, then President Daniel Arap Moi grudgingly allowed Somali refugees into Kenya on the condition that they reside only in the camps located near the border. Continued provisions of international development aid from Europe and North America to Kenya were conditional upon a proven commitment to democratic process and the country's acceptance of Somalis in need of humanitarian assistance, some of which would also benefit Kenya. During the Moi era in Kenya, a repeating pattern of events is discerned by analyst, Daniel Ehrenfeld who calls it "a sort of 'aid tango.". "First, Kenya wins its yearly pledges of foreign aid, and then the government begins to misbehave, backtracking on economic reform and flexing its authoritarian muscle. Sharp rebukes this, following which Kenya placates its benefactors and the aid is pledged anew."14

The recent humanitarian crisis in Somalia and neighbouring countries is a déjà vu: conflict and drought together precipitate new expressions of human displacement, with many people travelling to the Dadaab camps for food. The Dadaab refugee population grew from 308,784 in January
2011 to 463,602 in October 2011, an increase of more than $50 \%$ in less than a year. This resulted in an increase from three camps to six, though the latter were approved by the Government of Kenya (GOK) for refugee residence in late 2011. As with shelter, unfortunately, other infrastructure in health and water/sanitation has not kept pace with this growth. ${ }^{15}$ Like the early 1990s, conflict and drought have occurred together as a 'dual disaster', generating new waves of human displacement within Somalia and across both the Ethiopian and Kenyan borders with Somalia. ${ }^{16}$

Conditioning Aid and Crisis in Somalia and Kenya Today In 2011, conflict continues between the African Union troops who support the Western-backed government and Al-Shabab (more precisely HSM, Harakat Al-Shabaab alMujahideen), a youth movement of Islamist militants who aim to overthrow this fragile government. ${ }^{17}$ Drought has returned to the region, and is said to be the worst in sixty years. Some 3.2 million people in Somalia face starvation and many are inaccessible to humanitarian actors due to the actions of Al-Shabab. ${ }^{18}$

The Al-Shabab insurgency has reportedly 'leaked' into the Dadaab camps. Bulletins that Al-Shabab sympathizers are among the new arrivals of refugees are not uncommon among those refugees who live in the three original camps. ${ }^{19}$ Whether the kidnapping of the two Spanish doctors is an act tied to Al-Shabab or represents a kind of piracy that seeks ransom rather than political revenge for Kenyan military incursions remains unclear, yet many subsequent security incidents aimed at inflicting harm on Kenyan security forces suggest that Al-Shabab is present. In retaliation for Kenyan military incursions into Somalia in fall 2011, Al-Shabab made a public statement that Kenyans would pay for their violation of sovereignty and violence against Somalia. $^{20}$

The capacity of communities to cope with such distress and dual humanitarian crises is no doubt eroded by the fact that the displacement from previous rounds of conflict and environmental disaster has not been resolved. Chronic conflict over two decades and repeated drought has taken a terrible toll on the livelihoods and security of people in East Africa and the Horn.

Somalia's weak Transitional Federal Government, the Obama administration, and the United Nations have all blamed the anti-government group Al-Shabab for restricting international aid operations in the areas they control and preventing emergency food distribution. Al Jazeera reports that US policy on aid distribution has also contributed a drought and food crisis. ${ }^{21}$ While Al-Shabab has proven obstructionist in preventing the delivery of humanitarian aid to Somali citizens in dire need, it has produced evidence 
that the U.S. government has implemented its own conditions on the delivery of food aid to starving people.

Aid organizations in Somalia face strict regulations of food distribution in an effort to deprive Al-Shabab of food for its own forces. While famine conditions were known to be coming to South Central Somalia in the fall of 2011, no food aid was prepositioned there, despite such a strategy being used in other parts of the country, due to the strength and control of Al-Shabab, according to Tony Burns, director of a Somali NGO called SAACID. ${ }^{22}$ The United States Office of Foreign Assets Control (OFAC) monitors US food aid distributions in Somalia and elsewhere. OFAC imposed sanctions in Somalia to ensure that no material support, including food aid, would go to Al-Shabab to support its rebel activities. Accountability requirements for food distributions were so stringent that such recordkeeping was hard to manage outside of the capital, Mogadishu. Effectively, the OFAC rules were eventually loosened but not before many lives were lost. The main point here is that access to life-saving food aid was obstructed by Al-Shabab, but that securitizing emergency food for famine relief in policy can have an adverse impact on civilians. Humanitarian aid is supposed to be provided to support the right to life unconditionally, according the Sphere principles. ${ }^{23}$

As I have argued elsewhere, humanitarian assistance in general has become a de facto political tool through which the threat to world stability and resources represented by poor countries may be defused by development. ${ }^{24}$ Conditions placed on international aid are nothing new in development circles, but the more recent mantra of 'aid effectiveness' is particularly pernicious, given its broadly interpreted liberal democratic requirements of political and economic governance. Identified first by the Organization for the Economic Cooperation and Development (OECD) and promoted by the World Bank, 'strengthening aid effectiveness' is a salient neoliberal policy of development that aims to utilize international assistance most efficiently by eliminating countries with protectionist economic policies or corrupt, unstable governments from the aid recipient list. ${ }^{25}$ 'Good governance' and 'sound economic policy' are prerequisites for receiving international aid under this policy rubric. ${ }^{26}$

In theory, 'strengthening aid effectiveness' provides aid to the 'good' low-income developing countries that demonstrate market-orientated economic provisions and the rule of law, including a solid record of democracy and human rights, as well as low levels of corruption. Yet even if recipient governments do abide by the rules of donors from the global North, it has become apparent that states who donate funds to this region, both Somalia and the refugee camps in Kenya, do not hold themselves to the same standards of liberal democratic process, a point I return to in the conclusion.

\section{A Silent Emergency: Containing Displacement in Camps}

Despite the acute current humanitarian crises, few refugees fleeing Somalia for Kenya or Ethiopia will get beyond the camps in these initial countries of asylum, or will get Convention refugee status in Kenya or another country of asylum. Convention refugee status is a legal designation that allows refugees who are determined as bona fide to work and provides them with certain protection guarantees when residing in a host country.

Even refugees who arrived in Kenya in the early 1990s have not been afforded this status, as the Government of Kenya stopped granting such status at that time, despite being a signatory to the Convention. Instead, Kenya chooses to let them stay under a group designation with many fewer rights, as prima facie, refugees. In the Kenyan government's defense, why should it resettle and integrate hundreds of thousands of refugees when Kenya itself is a relatively poor country that struggles to educate and employ its own nationals?

In the short term, emergency humanitarian assistance is being provided to people inside Somalia and to new arrivals in desperate condition at the Dadaab camps. This will avert some death and suffering, and hopefully save lives. And yet just as the Northern Frontier District boundary and the Somali-Galla line it imputed kept Somalis contained in the district during colonial times, so too have refugees been sequestered in this impoverished and arid part of Kenya since their displacement from Somali in the years following the 1991 coup in Somalia.

Refugees in limbo in Dadaab face a long wait in protracted situations. Many if not most of their basic human rights are neglected, or ignored, but not by any one party, government, or force majeur. Instead, they receive minimal material provisions to keep them alive, housed, and in basic health. Refugee protection against refoulement may be guaranteed, but legal protection and pathways to some kind of status remain elusive for most. ${ }^{27}$ In Kenya, basic education up to the secondary level is provided, but the highest level available is not considered comparable to the Kenyan secondary school standard. Access to employment and mobility are suspended for years, even decades.

In the context of the three Kenyan camps adjacent to Dadaab, some refugees have lived there since the opening of the first camp, Ifo refugee camp, in 1992. In the mid-1990s, offering education beyond the primary level was thought to be an incentive for refugees to stay in the camps and avoid repatriation. Sixty percent of the refugees in Dadaab camps 
are poor or destitute and often "unable to meet their daily needs." 28

Refugee camps are always only supposed to be 'stopgap measures', but they have proven to be persistent. The average waiting time for refugees has increased from nine years in 1993 to 17 years in $2003 .^{29}$ The liberal democratic values of post-WWII planning gave rise to the international refugee regime, both the legal instruments and the Office of the United Nations High Commissioner for Refugees. And yet neither envisioned the protracted and long term camps where most human rights are, in fact, suspended until a more durable solution is found. ${ }^{30}$

The United States Committee for Refugees and Immigrants (USCRI) calls this 'refugee warehousing' and has launched a tireless campaign on behalf of these refugees for the better part of a decade. ${ }^{31}$ UNHCR reports that almost two-thirds of all refugees are in protracted refugee situations (PRS). ${ }^{32}$ Bailey et al. chronicle the case of Salvadoran asylum seekers in the US who have also remained in legal limbo for decades, calling their uncertainty and precarious legal status 'permanent temporariness', an apt term for people with prima facie group designation as refugees but without documentation or individual legal status to resume their lives. ${ }^{33}$

\section{Externalizing Asylum: Providing Protection Offshore}

Inasmuch as refugees lack basic human rights in long term camps, the donor states of the global North that support the food, medical, and housing assistance also actively deter asylum seekers from such camps from coming to their borders to make a refugee claim in a place where more rights might be available. Much has been written about the tactics used to deter asylum seekers from Europe, North America, and Australia, but rarely are these geopolitical practices brought to bear on protracted refugee situations such as those in East Africa and the Horn. ${ }^{34}$ Visas, readmission agreements and safe third country agreements are just a few examples of ways of keeping asylum seekers out and preventing them from making claims.

Asylum has been respatialized, by which I mean that the geopolitical valence of refugees has changed since the Cold War, resulting in efforts to assist refugees closer to their homes in 'regions of origin'. This occurred first in the early 1990s through a policy of 'preventive protection' and then in the 2000s through the externalization of asylum. ${ }^{35}$ Andrew Shacknove presciently signalled a diminished commitment to asylum after the Cold War ended, noting that "refugee policy has always been at least one part State interest and at most one part compassion." 36 The development of laws, policies, and practices to prevent asylum from being sought in the global North, thus, continues.
The principal architects of the externalization agenda are the European Commission, Denmark, the Netherlands, and Britain. ${ }^{37}$ Alexander Betts traces how a political space for special agreements on the secondary movement of refugees and asylum seekers was created by the UN High Commissioner for Refugees, Ruud Lubbers through the 'Convention Plus' initiative in 2002. ${ }^{38}$ The initiative aimed to provide a space that enhanced refugee protection 'in the region,' but simultaneously limited access to protection on European soil. As,

This is not simply a case of placing police and customs officials in third country airports-as Zolberg so cogently points out, but rather the gradual implementation of a system of migration management aligned with development assistance in third countries. ${ }^{39}$

Cooperation by transit countries and states of migrant origin is rewarded handsomely with development assistance from more affluent countries. Australia patronized Indonesia; Italy patronized Libya, until the Arab spring created new and unstable political relations there in the spring of 2011 .

In the early 2000s, UNHCR's 'Convention Plus' initiative promoted the local integration of refugees in countries near their homes as a durable solution to long-term displacement, including those in protracted situations. Yet this approach assumed that countries in the global South would be willing to take on additional responsibility for integrating refugees permanently, given the right mix of foreign aid and other financial incentives. It assumed that strengthening capacity to protect refugees in these initial countries of asylum could reduce the need for onward movement [to the global North] for refugees.

Yet, if "African states were to reduce their commitment to the principle of territorial asylum, thereby undermining access to effective refugee protection within the region, this would almost certainly exacerbate the likelihood of onward movement and global insecurity." 40 The authors observe that European states are willing to pay for, but not host refugees; these states' collective views are encapsulated in the conviction that “it doesn't matter where asylum is provided as long as it is provided." 41 The 'Convention Plus' initiative failed in its efforts to persuade first countries of asylum to settle refugees permanently, but one could argue that governments that are signatories to the Convention have succeeded in externalizing asylum offshore, away from their territory where asylum seekers can access rights once they land and file a claim. Protracted refugee camps are one symptom of these geopolitical tactics.

The war in Somalia continues in fits and starts, precluding any possibility for large-scale return. The Government 
of Kenya will not consider local integration for Somali refugees, or any other refugees for that matter. The recent political violence and loss of life in Kenya in addition to the long history of ethnonational politics and conflict in Kenya's northeast do not make it a palatable place for such refugees to live in the long term. Currently, their status is temporary and their mobility is constrained. While camp borders are porous to an extent, they cannot officially leave the camps. They do have legal status to live in Kenya beyond the humanitarian structures of Dadaab.

\section{Global Education, Local Limitations}

The region's political backdrop is layered, from the colonial transition to independence to the Cold War and now humanitarian aid. The fine line between lifesaving humanitarian aid and refugee protection in the full legal sense is blurred at best. Refugee education is controversial in the camps to the extent that it is not needed for survival and therefore not pertinent to humanitarian operations. Yet for refugees stuck in the 'stopgap-measure-camps', refugee education is essential and codified in international refugee law. It is part of the liberal democratic discourse of rights. As Assistant UN High Commissioner for Refugees, Erika Feller, recently recounted:

Education is one of the highest priorities of refugees, and has a vital role to play in their protection and ability to find sustainable solutions. Access to education is, though, limited. Refugee enrolment in primary school is only 76 per cent globally and drops to 36 per cent at secondary level. Girls are at a particular disadvantage. In East Africa and the Horn, for example, only five girls are enrolled for every 10 boys. $^{42}$

Education has been declared a 'tool of protection' by UNHCR and a durable solution for refugees by scholars of 'education in emergencies' (EIE). ${ }^{43}$ According to article 22 of the 1951 Convention, signatory states "shall accord to refugees the same treatment as is accorded to nationals with respect to elementary education.... [and] treatment as favourable as possible ... with respect to education other than elementary education." 44

Just as refugee education is a right, it is also a development tool. It can also be construed as a protection tool if host governments are willing to settle permanently refugees with education and skills over those without. Most persuasively, refugee education is a portable skill set that is transferable with the person who obtains it, following them wherever they may go.

Refugee education is also a resource in developing countries. Educational services for refugees may exceed the quality and quantity of education offered to the local population or adjacent countries that have experienced chronic conflict. I draw here on the work of Epstein who speaks of "the education refugee", specifically "those who have the means to seek asylum across frontiers in order to access an education not otherwise available." ${ }^{\prime 4}$ Epstein provides evidence of such migrations from Sudan to Kenya, foregrounding the case of South Sudanese children who grew up in chronic conditions of war, where education was provided sporadically, if at all.

In a context where families and communities are often divided or dispersed by the upheaval of conflict, schools are seen as key institutions that will play the major role in rebuilding core values, in instilling new democratic principles, and in helping children recover a lost childhood. ${ }^{46}$

What is most relevant for my argument here is Epstein's finding that the curriculum of refugee education in the Kenyan context for Sudanese refugees accentuated liberal democratic values. The curriculum in camp schools overseen by UNHCR in Kenya stood in contradistinction to that of Khartoum schools where Islamification and Arabization agendas prevailed. ${ }^{47}$ Epstein describes one of the students from Sudan who travelled to the Kakuma refugee camp in Northern Kenya for his First World influenced education:

Seven years after reaching Kakuma and enrolling in school, joining the Boy Scouts, performing AIDS awareness skits in drama club, making videos about the drawbacks of polygamy and alcoholism in film club, working in a video hall where tickets were sold to view screenings of Chuck Norris movies, and being elected as a youth representative to the camp management council, Bol, now 22 years old and with a high school diploma in hand, returned to his village. He quickly found a job as a primary school teacher in a private school funded by a former neighbor who now lives in the United States, and as an agricultural project manager with a international non-governmental organization (INGO). ${ }^{48}$

The values of the Boy Scouts, the rights of persons with HIV/AIDS, the cultural politics of polygamy and alcoholism, and the experience with democratic process and representation are all part and parcel of a liberal democratic state with a functioning government to protect individual and group rights. National curriculum is also integrated into Kenyan refugee camps, so to argue that refugee education is simply a 'Western import' is to overstate the case.

Yet the vast majority of refugees in Kenyan camps are Somalis who cannot go home. They have none of the legal status, rights, or entitlements that are codified in the 1951 Refugee Convention and 1967 Protocol, endorsed and signed by the vast majority of countries in the global North. 
Ironically, the international refugee regime has largely failed to deliver much more than survival aid in protracted refugee situations, such as this one. ${ }^{49}$ My point is that these refugees experience little of the liberal democracy and rights in the curriculum taught in camp schools, despite talk of civil society, liberal peace, and human rights. In the Dadaab camps, a minimal form of protection from refoulement (forced return) is provided, but without any solution to this supposedly temporary situation.

\section{Concluding questions for further thought}

Refugee students may be taught to be global citizens: to value human rights in the context of liberal democracies, and to work in the spirit of voluntarism to benefit those less fortunate then they are, only to personally experience containment in camps. In the camps, their own educational and vocational pursuits are truncated, and a sense of 'permanent temporariness' prevails, not to mention desperation and depression. ${ }^{50}$ They are taught civics and the substance of what it means to be a good liberal subject, and yet are denied access to these most basic concepts and human rights in the context of the camps.

I have argued here that refugee camps are anything but neutral, purely humanitarian spaces. In East Africa and the Horn, they exist in contested territory with long histories of geopolitical disputes. The Cold War and the rising prominence of the Covenant on Civil and Political Rights after World War II led to the dominance of human rights that embodies freedom of expression, movement, and democratic process. Yet these principles have been largely abandoned in practice by states in Europe, North America, and Australia. They have been replaced by measures that aim to keep refugees and asylum seekers away from their borders. ${ }^{51}$ The post-WWII human rights-based regime of global governance, itself an expression of liberal democracy, has largely been supplanted by concepts like 'human security', practiced as selective security, which I contend signals the geopoliticization of human life.

\section{Notes}

1. Jennifer Hyndman and Wenona Giles, "Waiting: Linking Protracted Refugee Situations to Asylum Policies in the Global North," Gender, Place, and Culture 18, no. 3 (2011): 361-79.

2. UNHCR [United Nations High Commissioner for Refugees]. State of the World's Refugees Oxford/New York: Oxford University Press.

3. Jennifer Hyndman. Managing Displacement: Refugees and the Politics of Humanitarianism. Minneapolis: Minnesota University Press, 2000.
4. Jennifer Hyndman, "A Post-Cold War Geography of Forced Migration in Kenya and Somalia," in The Professional Geographer 51, no. 1, (London: Routledge, 1999), 104-14.

5. Hyndman, "Managing Displacement," 2000

6. Hyndman, ibid. 2000

7. Olara Otunnu, "Factors Affecting the Treatment of Kenyan-Somalis and Somali Refugees in Kenya: A Historical Overview" in Refuge, 12, no. 5, (North York, Ontario: York Lanes Press, 1992), pp. 21-25.

8. Hyndman, "Managing Displacement," 2000

9. African Rights, "Humanitarianism Unbound? Current Dilemmas Facing Multi-Mandate Relief Operations in Political Emergencies," discussion paper no. 5, (London, 1994).

10. Hyndman, "Managing Displacement," 2000

11. Hyndman, ibid. 2000

12. Ottunu, "Factors Affecting the Treatment," 1992.

13. BBC [British Broadcasting Corporation], "Spanish MSF doctors seized near Kenya-Somali border," BBC News, Oct 13, accessed Dec. 31, 2011, http://www.bbc.co.uk/news/ world-africa-15293502.

14. David Ehrenfeld. "Foreign Aid Effectiveness, Political Rights and Bilateral Distribution," in The Journal of Humanitarian Assistance, Feb. 1, 2004, accessed January 23, 2012, http://sites.tufts.edu/jha/archives/75

15. Maureen Kopiyo and M. Njogu, "An Overview of Dadaab Refugee camps", (a paper for the Borderless Higher Education for Refugees (BHER) workshop, Kenyatta University, Nairobi, Dec. 2, 2011.)

16. Jennifer Hyndman, Dual Disasters: Humanitarian Aid after the 2004 Tsunami (Sterling VA: Kumarian Press), 2011.

17. Inter-agency Network on Education in Emergencies (INEE) "Crisis Update 2: Drought in Horn and East Africa," 2011, accessed August 16, 2011, http://campaign.r20 .constantcontact.com/render?llr $=$ w6v6qlcab\&v=001avab2lDATeP8NR17X7pqALKYcNMsiz86-2-8clY4Mz2NO xLSwOU4OulbfIGY60TBe1_i6EdBkpIpw0B6YSEUAF7 1AY5Utazej6Jny8gBZsxLRBNim-AyNgmLCuY9sU0jA5Vc0slD-CpZnwLJn4mOQg\%3D\%3D.

18. Inter-agency Network on Education in Emergencies (INEE) "Crisis Update 2: Drought in Horn and East Africa," accessed August 16, 2011, http://campaign.r20.constantcontact.com/render?llr $=$ w6v6qlcab $\& v=001 \mathrm{avab} 2 \mathrm{lDATeP}$ 8NR17X7pqALKYcNMsiz86-2-8clY4Mz2NOxLSwOU4OulbfIGY60TBe1_i6EdBkpIpw0B6YSEUAF71AY5Utazej6Jny8gBZsxLRBNim-AyNgmLCuY9sU0jA5Vc0slDCpZnwLJn4mOQg\%3D\%3D.

19. Private conversations with community researchers based in Ifo, Dagahaley, and Hagadera at a workshop in Nairobi in December 2011 confirmed that fear of Al-Shabab permeates the camps. Refugees are afraid of insurgents, and Kenyan security forces are fearful that Al-Shabab has infiltrated the camps, given rise to increased suspicion of all Somalis, refugees or combatants.

20. France24, "Somali Islamists vow to retaliate for Kenyan offensive," Oct. 27, 2011, accessed January 23, 2012, 
http://www.france24.com/en/20111027-kenyan-troops -shabaab-militants-call-revenge-attacks-somalia-islamists -kidnappings.

21. Al Jazeera, "Horn of Africa Crisis: Somalia's Famine," Faultine, accessed Dec. 5, 2011, http://www.aljazeera.com/ programmes/faultlines/2011/11/201111271473753430. html

22. Al Jazeera, "Horn of Africa Crisis," 2011.

23. "The Sphere Project: Humanitarian Charter and Minimum Standards in Humanitarian Response," accessed January 23, 2012, http://www .sphereproject.org/sphere/en/community/calendar/ training-on-sphere-principles-and-standards/.

24. Jennifer Hyndman, Dual Disasters: Humanitarian Aid after the 2004 Tsunami (Sterling VA: Kumarian Press).

25. World Bank, Assessing aid: What works, what doesn't and why, (New York: Oxford University Press, 1998).

26. OECD, "Developing countries, meeting of the council at ministerial level," article 23, (May 1992), accessed 8 July 2008, www.g7.utoronto.ca/oecd/oecd92.htm.

27. Hyndman and Giles, "Waiting: Linking Protracted Refugee Situations," 2011.

28. Horst, Globalization of Protracted Refugee Situations: Kenya Case Study Fieldwork Report (unpublished). Presented at IASFM meetings, Cairo, January 2008, p. 10.

29. United Nations High Commissioner for Refugees [UNHCR], State of the World's Refugees (Oxford/New York: Oxford University Press, 2006).

30. Jean-Francois Durieux and Jane McAdam, "Non-Refoulement through Time: The Case for a Derogation Clause to the Refugee Convention in Mass Influx Emergencies," International Journal of Refugee Law, 16, no. 1, (2004): 4-24.

31. United States Committee for Refugees and Immigrants [USCRI], "Warehoused Refugee Populations," World Refugee Survey 2008, accessed June 30, 2008, www.refugees. org/uploadedFiles/Investigate/Publications_\&_Archives/ WRS_Archives/2008/warehoused $\% 20$ refugee $\% 20$ populations.pdf

32. UNHCR, "State of the World's Refugees," 2006.

33. A. J. Bailey, R. A. Wright, I. Miyares, and A. Mountz, "Producing Salvadoran Transnational Geographies," Annals of the Association of American Geographers 92, no 1, (2002): 125-44.

34. Michael Samers, "An Emerging Geopolitics of 'Illegal' Immigration in the European Union," European Journal of Migration and Law 6, (2004): 27-45; Alison Mountz, Seeking Asylum: human smuggling and bureaucracy at the border. (Minneapolis: University of Minnesota Press, 2010); and Jennifer Hyndman and Alison Mountz, "Another brick in the wall? Neo-refoulement \& the externalisation of asylum in Europe \& Australia," Government \& Opposition, 43, no. 2, (2008): 249-69.

35. Hyndman, "Managing Displacement," 2000; Hyndman and Mountz, "Another brick in the wall?" 2008.
36. A. Shacknove, "From Asylum to Containment" in International Journal of Refugee Law, 5, no. 4, (1993): 516-33, p. 517.

37. Alexander Betts and James Milner, "The Externalisation of EU Asylum Policy: The Position of African States," Centre on Migration, Policy and Society, working paper no. 36, (University of Oxford, 2006).

38. Betts, 2004

39. Samers, “'An Emerging Geopolitics,” 2004, p. 43.

40. Betts and Milner, "The Externalisation of EU," 2006, p. 4.

41. Betts and Milner, ibid, p. 8.

42. Erika Feller [Assistant High Commissioner for Refugees, UNHCR], "Doing Protection Better," Statement of the $\mathrm{AHC}(\mathrm{P})$ at the 62nd Session of the Executive Committee, 5 October 2011

43. Dryden-Peterson, op. cit.

44. Ibid. p. 13.

45. A. I. Epstein, "Education Refugees and the Spatial Politics of Childhood Vulnerability", Childhood in Africa 2, no. 1, (2010): 16-25, p. 18.

46. World Bank 2005 cited in Epstein, 2010, ibid. p. 16.

47. Epstein, ibid, 2010.

48. Epstein, ibid, 2010.

49. Hyndman and Giles, "Waiting: Linking Protracted Refugee Situations," 2011.

50. A. J. Bailey, R. A. Wright, I. Miyares, and A. Mountz, "Producing Salvadoran Transnational Geographies. Annals of the Association of American Geographers 92, no. 1, (2002): $125-44$.

51. M. Dikec, “The 'where' of asylum," Environment and Planning D: Society and Space 27, (2009): 183-89.

Jennifer Hyndman is Professor in Social Science and Geography at York University in Toronto, Canada, and Associate Director of Research at the Centre for Refugee Studies there. Her research focuses on the geopolitics and securitization of forced migration from conflict zones and refugee camps to resettlement in North America. She is the author of Dual Disasters: Humanitarian Aid after the 2004 Tsunami (2011), Managing Displacement: Refugees and the Politics of Humanitarianism (University of Minnesota Press, 2000), co-editor of Sites of Violence: Gender and Conflict Zones (University of California Press, 2004), among other publications. 
(C) Jennifer Hyndman, 2011. This open-access work is licensed under a Creative Commons Attribution-NonCommercial 4.0 International License, which permits use, reproduction and distribution in any medium for non-commercial purposes, provided the original author(s) are credited and the original publication in Refuge: Canada's Journal on Refugees is cited. 